\title{
Students Attitudes toward English Conversation Class in the Ways They are
}

\author{
Mara Sutan Siregar \\ Department of English Applied Linguistics \\ Universitas Negeri Medan \\ Medan, Indonesia \\ marasutansrg@gmail.com
}

\author{
Amrin Saragih \\ Department of English Applied Linguistics \\ Universitas Negeri Medan \\ Medan, Indonesia
}

\author{
Rahmad Husein \\ Department of English Applied Linguistics \\ Universitas Negeri Medan \\ Medan, Indonesia
}

\begin{abstract}
English conversation is one of the crucial lessons for senior high school students in order to face the globalization. Many students considered English conversation as a controversial lesson through their positive and negative attitudes toward it. This study aimed to reveal the realization of students' attitudes toward English conversations class in the ways they are. This was a qualitative study conducted at the twelfth grade of senior high school students. The subjects of this study were 20 students at the age of 16-17 years old. Data were collected by doing observations, and interviews. The data were analyzed using Interactive Models. The result showed that students tended to have the positive language attitudes toward English conversations class in various ways. It was found that there were many factors influencing their attitudes i.e. awareness of language use, language loyalty, language pride and lack of knowledge. It was concluded that the realization of students attitudes toward English conversation were various.
\end{abstract}

Keywords—language, attitudes, conversations

\section{INTRODUCTION}

People in society create the interaction through the communication in daily life. To communicate each other the people need language as the tools for communication. Through the language there are interaction among people to exchange the information, thoughts, and feelings. The activities of exchanging information, thoughts and feelings in other word are called by conversation. Conversation class lessons can be on one or more of the language skills or fully integrated practice sessions such as: formal, polite, interviews, presentations, face-to-face and everyday conversations [1]. Conversation is also one of the most basic and pervasive forms of human interaction [2]. The process of exchanging information, the attitudes often appear in responding the information acquired from the other people. An attitude represents an evaluative integration of cognitions and affects experienced in relation to an object [3]. Attitudes are the evaluative judgments that integrate and summarize these cognitive/affective reactions. These evaluative abstractions vary in strength, which in turn has implications for persistence, resistance, and attitude-behavior consistency. The attitudes also consist of affect, judgment, and appreciation which they are realized by direct or indirect, and oriented in positive or negative. Affect deals with feeling, judgment deals with characters or behavior, and appreciation deals with value [4]. The following figure is shown to explain the mind mapping of students' attitude toward English conversation class.

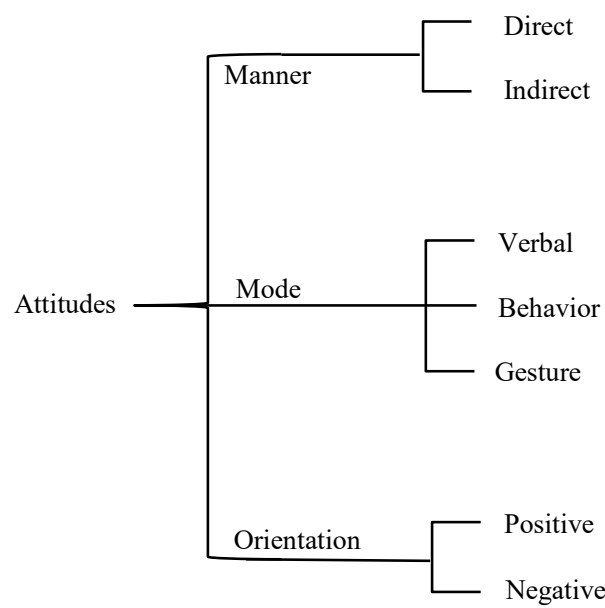

Fig. 1. The Realization of Attitudes [4]

It was assumed that the realizations of students' attitudes toward English conversation class are as follow:

- $\quad$ direct/verbal/positive]

- $\quad$ indirect/verbal/positive]

- [direct/behavior/positive]

- $\quad$ indirect/behavior/positive]

- [direct/gesture/positive]

- $\quad$ indirect/gesture/positive] 
- $\quad$ direct/verbal/negative]

- $\quad$ indirect/verbal/negative]

- [direct/behavior/negative]

- [indirect/behavior/negative]

- [direct/gesture/negative]

- $\quad$ indirect/gesture/negative].

The students often show their attitudes in several ways in the process of teaching and learning of English conversation subject. The recent study found that the EFL students showed negative attitudes toward learning English. [5] It meant that when in teaching and learning process of English conversation, some students did not participate in the classroom activities, some also did not want to speak, some others were not confident to speak, but some of them were serious in learning, and some others were also confident in speaking English. The other study related to this research found that positive attitude of ELF students toward English learning in three aspects of behavioral, cognitive, and emotional [6].

Meanwhile it was expected that students should be able to speak English well as the learning objective of English subject particularly in English conversation class. So that is why, English conversation is the application of the speaking skill in teaching English. Factually, the problems of the students which were found in SMA Al-Hidayah Medan namely; students were worried about saying things in English in the classroom because of simply being shy of the attention that their speech attracts; students had no motive to express themselves, i.e., the guilty feeling that they should be speaking; low or uneven participation, this meant that the tendency of some students to dominate, while others speak very little or not at all; students tended to share mother tongue. Finally, it was considered important to conduct the research toward this phenomenon to reveal the way of students in realizing their attitudes toward English conversation class.

\section{METHOD}

This research was conducted on students of Senior High School (SMA) Al-Hidayah Medan located at Jl. Letda Sudjono Gg. Perguruan No. 4 Medan, Indonesia in 2018/2019 academic year. The subject of this study consisted of 20 students with the average age were 16 to 18 years old. This research conducted using qualitative descriptive analysis. The data of this research were the students' utterances and behavior toward English conversation class.

The data of this research were collected by doing observation and interview. The process of collecting data was supported by interview transcript and some other instruments i.e field note; and audio/video recorder in order to get the students' utterances, and behaviors. Then, the data were analyzed by applying interactive models [7]. The steps were data condensation, data display, and data drawing/verification. Finally, the trustworthiness of the study was based on credibility, transferability, dependability and conformability [8].

\section{DAta ANALYSis}

Attitudes were realized directly and indirectly. Then the way of realizing the attitudes were through verbal, behavior and gestures, the last, the orientation or the meaning realized from the attitudes can be positive or negative [4].

\section{A. Students Attitude toward English Conversation Class}

Attitude towards English conversation in this study has been defined as the students' perceptions, understandings, beliefs or experiences in learning English conversations. Attitude is a mental process which is heavily influenced upon the response that the individual show while performing a task. In layman terms, it is how learners react when they are asked to perform the task. It is expressed in two ways, the positive manner when they are interested in performing the given task and negative manner, when they are forced or not interested in performing the task. This is again influenced by the learner's background. The data showed that students realized their attitudes in positive and negative ways. The percentages of the respondents' attitudes towards English conversations shown in Fig. 2.

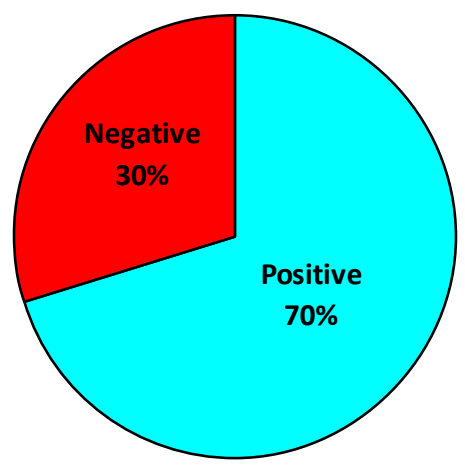

Fig. 2. The Percentages of Students' Attitudes

The percentages of students' attitude toward English conversation class show that positive attitude is more dominant than the negative attitude or $70 \%$ greater than $30 \%$. The data were also supported by the following interview:

\section{Data 1}

Interviewer : do you like English conversation class?

Student : of course I really like it.

Interviewer : why do you like English conversation class?

Student : Because, English is a cool language, it is needed in many workplaces, that's why I like it.

Data 1 shows that the student did like English conversation class. It shows the positive attitude toward English conversation class. In accordance with the positive language attitudes types, positive attitudes support efforts to use the language in variety of domains [9]. It meant that a positive language was an eagerness of the student to use the language in all domains. Therefore, the positive language attitudes were considered important toward English conversation class.

As attitudes also affected by a behavior, below is the transcription of student's behavior during the English conversation class. 
Data 2

Student : (Raising hand and interrupted) Use English full sir?

Data 2 shows that the positive attitudes realized by the students through their behaviors. It can be seen that student showed the positive behavior by giving interruption to the teacher and asking to use English fully in the classroom. It described that he/she wanted to use English in the classroom rather than Bahasa Indonesia. It was a positive attitude because he/she preferred to use English during English conversation class.

In contrast, below is the example of negative attitude from the student:

\section{Data 3}

Interviewer : do you like English conversation class?

Student : no, because I don't like English

Interviewer : what is your effort to study English conversation class?

Student : nothing else.

Data 3 shows that the student did not have any effort to use or studying English conversation. This was a negative attitude shown by the student because he/she did not like English. According to the factor of negative language attitude, Data 3 were against the language loyalty. The student did not have any loyalty to speak English, and he/she also did not have any effort to use English in English conversation class.

It is shown from all the percentages of the students' attitudes toward English conversation class that the dominant type of attitude was positive.

\section{B. The Way of Students Realize their Attitudes}

Attitudes were realized directly and indirectly then the way of realizing the attitudes were through verbal and behavior. The orientation was realized in positive or negative. Based on the data observations, it was found that students' realize their attitudes as seen in Fig. 3.

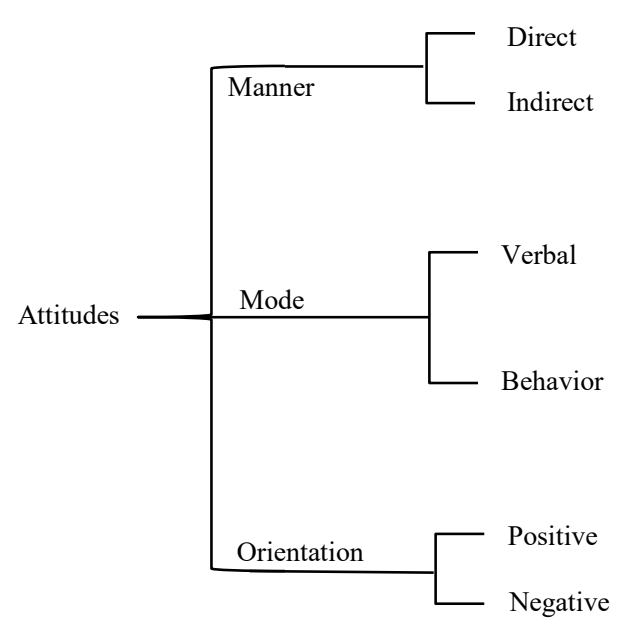

Fig. 3. The Realization of Students' Attitudes
The percentages of students' attitudes realization can be seen in TABLE I.

TABLE I. The Proportion of Attitude ReAlization

\begin{tabular}{|c|l|c|c|}
\hline No. & Realization & Number & Percentages \\
\hline 1 & {$[$ Direct/Verbal/Positive] } & 1 & $5 \%$ \\
\hline 2 & {$[$ Direct/Verbal/Negative] } & 2 & $10 \%$ \\
\hline 3 & {$[$ Indirect/Verbal/Positive] } & 7 & $35 \%$ \\
\hline 4 & {$[$ Indirect/Verbal/Negative] } & 2 & $10 \%$ \\
\hline 5 & {$[$ Direct/Behavior/Positive] } & 4 & $20 \%$ \\
\hline 6 & {$[$ Direct/Behavior/Negative $]$} & 2 & $10 \%$ \\
\hline 7 & {$[$ Indirect/Behavior/Positive $]$} & 2 & $10 \%$ \\
\hline 8 & {$[$ Indirect/Behavior/Negative $]$} & 0 & $0 \%$ \\
\hline \multicolumn{2}{r|}{ Total } & 20 & $100 \%$ \\
\hline
\end{tabular}

\section{1) [Direct/Verbal/Positive]}

The realization of attitude included behavior [4]. The way of students in realizing their positive attitudes can be spoken directly. Shortly, it was stated that [direct/verbal/positive] attitude was the students' positive utterances with the positive meaning during the English conversation class which were spoken directly. Below is the example of student utterances in verbal way.

\section{Data 4}

Student : (Raising hand and interrupted) Use English full sir,?

It can be seen that the student spontaneously respond the teacher by his interruption. Based on the level of attitudes it was belonging to valuing the phenomenon and it was a positive attitude. He/she wanted the teacher spoke English fully during the English conversation class. It also showed that the student responded the teacher directly and verbally. It was a positive attitude based on the level of attitude namely responding [10]. It was stated that the student responded and participated actively. The student not only attended the class but also reacted in positive way. This was verbal and direct attitude shown by the student towards English conversation class. The level of attitude shown in Data 4 was responding. Referring to the levels of attitude realization, responding means respond and actively participate. It can be seen that the student voluntarily offering himself/herself to perform before the teacher asked him/her to perform.

\section{2) [Direct/Verbal/Negative]}

This was contrast with the [direct/verbal/positive] attitude. The [direct/verbal/negative] students' attitude toward English conversation class realized through spoken directly. Shortly, it was stated that [direct/verbal/negative] attitude was the students' negative utterances with the negative meaning during the English conversation class which were spoken directly. Below is the example of student utterances in verbal way.

Data 5

Student : (teacher asked to perform in front but she refused to speak English in the class) Gak usah lah pak (no need to sir). 
Data 5 shows the negative attitude from the student which was stated verbally and directly in the process of English conversation learning process. The respond of the student showed a negative meaning because the student did not participate actively in the class. The [direct/verbal/negative] shown by the students can be seen when they did not speak English instead of bahasa Indonesia directly in performing the conversation practice. It was seen also that they did not have a loyalty toward English conversation as one of the indicator of positive language attitude was having the loyalty to use and speak English in many domains including in the English conversation learning process.

\section{3) [Indirect/Verbal/Positive]}

The utterances of students outside the learning process with the positive value called [indirect/verbal/positive] attitudes. The utterances were got from the interview done to the students to gain the data of their attitudes. Below is the example of [indirect/verbal/positive] attitudes of students.

Data 6

Student : I like English conversation class because this lesson is very important for all of us it make us easy to get the job.

The Data 6 shows the positive attitude. It was stated indirectly in learning process of English conversation class. It also showed the awareness of the student about the importance of English as foreign language through the English conversation class. It is seen that the student realized the importance of English conversation class because of the student expected to get the job vacancies through English skill he/she had. It was a language pride expressed by the student because he/she felt that learning English conversation was more important for him.

\section{4) [Indirect/Verbal/Negative]}

The [indirect/verbal/negative] attitude was expressed by the students outside the learning process of English conversation. The data of this negative attitude were acquired from interviewing the students. The example of data is seen in Data 7.

\section{Data 7}

$\begin{array}{ll}\text { Interviewer } & : \text { do you like English conversation class? } \\ \text { Student } & : \text { no, because I'm not a British. }\end{array}$

Data 7 shows the negative attitude of student toward English conversation class. The student did not like English conversation class because of he/she is not a British. It was not a loyal attitude shown by the student toward English conversation, and it was a negative attitude. In line with the negative language attitude indicators, the Data 7 describes that the student did not have a loyalty in learning English conversation class.

\section{5) [Direct/Behavior/Positive]}

The attitudes realized by the students toward English conversation class also came from their behavior during the English conversation learning. The data of observation showed that students realized positive attitudes behavior. The example of data as follow:

\section{Data 8}

Student : (Rising hand and offering to perform in front of the class) we sir.

The Data 8 shows that the student responded the teacher directly. It was a positive attitude based on the level of attitude namely responding [10]. It was stated that the student responded and participated actively. The respondent not only attended the class but also reacted in positive way. The respond of students was reacting and participating when the teacher gave him/her instructions. It was a positive attitude from the student toward and during the English conversation class. The direct behavior of students' positive attitude can be seen from their spontaneous action to raise their hand and offering to perform in front of the class. It meant that student has participated actively and he/she had a good motivation to speak English in front of the class.

\section{6) [Direct/Behavior/Negative]}

The attitudes realized by the students toward English conversation class also came from their negative behavior during the English conversation learning. The data of observation showed that students realized negative attitudes behavior. The example of data as follow:

\section{Data 9}

Student : (Talking with her friend during the others performance) apa yang mau dibilang? (what should I say?) (did not listen and respond the teacher actively).

The Data 9 shows the negative attitude identified from student's behavior during the English conversation class. It was seen that he/she talked with others while his/her friends still performing the conversation in front of the teacher. Moreover, he/she also did not listen and respond the teacher actively in the classroom. The student also refused the teacher to speak English and directly gave interruption. He/she stated that he/she did not understand what the teacher said in English. This was a negative behavior showed by the student toward the English conversation class.

\section{7) [Indirect/Behavior/Positive]}

Indirect behavior of students can be seen from respond of students during English conversation class. These behaviors were identified based on their respond and participation in the class without any direct action. For example when the teacher gave instruction or explaining the lesson, the students tended to keep silent, and listened to teacher without any direct movement or action. The TABLE II below shows the positive indirect behavior of students.

TABLE II. The Positive IndiRect Behavior of StUdents

\begin{tabular}{|c|ll|}
\hline Data & \multicolumn{1}{|c|}{ Positive Indirect Behaviors } \\
\hline Data 10 & 1. & $\begin{array}{l}\text { Listen and respond actively } \\
\text { Use English in the class }\end{array}$ \\
\hline
\end{tabular}


TABLE II shows that students have the [indirect/behavior/positive] during the English conversation class. They tended to listen and respond actively without any positive direct action. In addition, they also mixed bahasa Indonesia when they did not understand about some words rather than using bahasa Indonesia dominantly in the process of teaching and learning of English conversation. Those [indirect/behaviors/positive] were in line with the level categories of attitude namely the level of receiving. In this level the students were willing to pay attention and listen with respect. Receiving represents the lowest level of learning outcomes in the affective domain. In other hand, there was no data identified related to the [indirect/behavior/negative] because this data consisted of the behavior of students outside the English conversation class meanwhile this study only focused on the students' attitude toward the English conversation class.

After discussing all the students' attitude realization, then the data are displayed to see the percentages of the realization as follow:

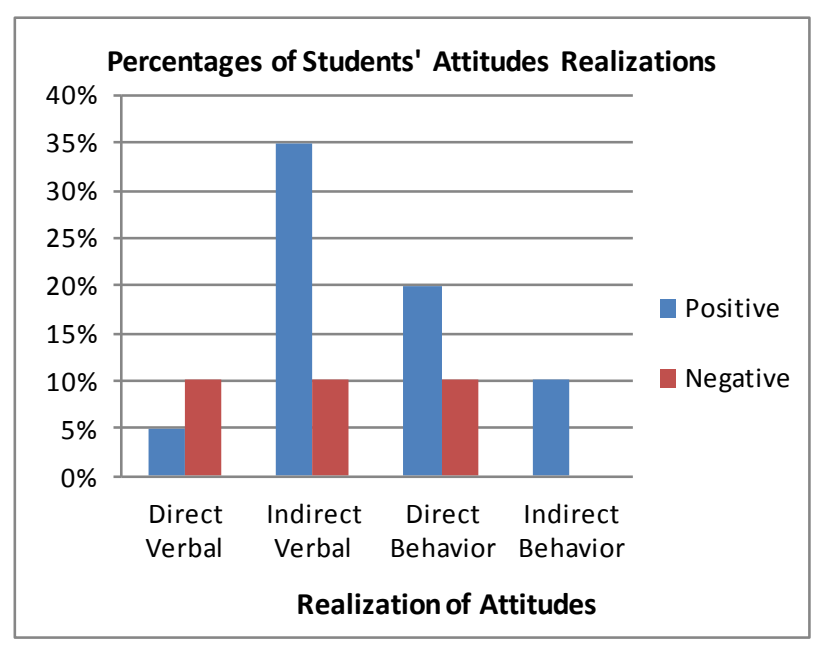

Fig. 4. The Proportion of Students Attitudes Realizations

Fig. 4. shows the percentages of students attitude realization which dominated by [Indirect/Verbal/Positive] namely $35 \%$.

\section{FINDINGS}

The dominant attitude shown by the students toward English conversation class namely $70 \%$ of positive attitude meanwhile the negative attitude was $30 \%$. It means that the positive attitude shown by the students was greater than negative attitude. The realization of attitudes also in various ways, [direct/verbal/positive] 5\%, [indirect/verbal/positive] $35 \%$, [direct/behavior/positive] 20\%, [indirect/behavior/positive] $10 \%$. It means that one student can realize his/her attitude in many ways it can be direct verbally followed by behavior. In other hand, the negative attitude of students consist of $30 \%$ realized in three ways i.e. [direct/verbal/negative] 10\%, [indirect/verbal/negative] $10 \%$ and [direct/behavior/negative] $10 \%$. It means that besides the students realized their attitude in verbal ways at the same time they also realized their negative attitude through their behavior. The respondent gave their reason about their attitudes in many reasons related to the indicators of language attitude namely, awareness of language use, language loyalty, language pride and lack of skill. Besides, they gave reason for self satisfactions, it was also found that dominantly respondent gave the positive attitude toward English conversation class because of motivation to get the job in the future. Furthermore, the respondents who realized the negative attitude were aware of the important of English conversation class in their future. In addition, the respondents who realized the negative attitudes toward the English conversation affected by the lack of skill.

\section{DISCUSSION}

This research has found that there were two types of attitudes of senior high school students toward English conversation class namely positive and negative. This study has found that the cognitive aspect of attitude was the greater than the others namely $70 \%$. In line with this findings, it was relevant with the positive attitude of EFL students toward English learning in three aspects of behavioral, cognitive, and emotional [6]. It means that cognitive aspect can affect the attitude of a student toward English conversation class. The other researchers also found the types of students attitudes toward English language learning consist of positive and negative. It was exposed that the attitude towards English language learning and using the language in various domains of usage is extremely positive. The data also revealed that most of the students had negative feelings or fear regarding classroom instructions in their learning experience [11].

This research also found that the realizations of students' attitudes were in seven ways. The realization of attitudes also found on female and male students' attitude towards English as a Second Language regarding three aspects of attitude, i.e. behavioral, cognitive and emotional. [12] Furthermore, a study concerning on Students' Attitude towards English Language Learning and their Academic Achievement among First Year Engineering Graduates found that the realization of the students attitudes were in statements or utterances. [13]

This research also found there are four reasons of why the students realize their attitudes in the ways they are i.e. awareness of language use, language loyalty, language pride, and lack of skill. It was relevant with the majority of students feel that they have benefited from the conversation class in different domains; yet, many required a clearer outline of the course [14]. It means that students also get their self satisfied by learning English language. The students of Science subjects also exposed significantly higher learning attitudes towards EFL compared to the students of arts subjects [15]. It means that the students' awareness of the use of English in science also affects their attitudes toward English language learning. Furthermore, the positive attitudes included feeling that the English-only policy helped students to improve their English proficiency, prepare them for the high demands of using English proficiency in real-world interaction [16].

The previous study found that students appreciate English as a global language, but they are not committed to learn it at school [17]. In other hand the negative attitudes shown by the 
students in this study also found in Students of Islamic Education System have the negative attitudes and low motivation toward learning the English language [18]. It means that the students did not have the loyalty to use English in several domains. Other research about the relationship between Saudi EFL students' attitudes towards learning English and their academic achievement also found that the students have overall positive attitudes towards learning EFL [19]. It also found on the Sudanese undergraduates were many of Sudanese students did not like English because of the lack of their English skill [20]. The attitudes of English students of Jordanian undergraduate toward the standard Arabic appeared to be apathetic in general and several factors affected their attitudes were the lexical gap, literacy and education [21]. It can be seen that the lack of language skill can affect the students attitudes toward a certain language.

\section{CONCLUSIONS AND SUGGESTIONS}

\section{A. Conclusions}

The attitudes had by the students toward English conversation class dominantly positive. The students realized their attitudes in many ways such as [direct/verbal/positive], [indirect/verbal/positive], [indirect/behavior/positive], [direct/behavior/positive], [indirect/verbal/negative] and [direct/behavior/negative] which dominantly in [direct/verbal/positive]. The dominant reason of students in having the positive attitudes toward English conversation class because of specific purpose i.e. for getting job.

\section{B. Suggestions}

It is suggested to school authorities particularly the English conversation teachers to give more motivation and apply more teaching methods in order to grow up the students' motivation in English conversation teaching and learning. Next, the language researchers should do further research about the relationship of English conversation skill toward the successfulness of student in getting the job after graduation. The last, the English conversation teachers should give more trainings and practices particularly in English for specific purpose to facilitate the students in order to get the job.

\section{REFERENCES}

[1] H. Brown, Principles of Language Learning and Teaching. 6th ed. Pearson: Pearson Education, 2014, pp. 281.

[2] K. Baily, Practical English Language Teaching : Speaking. New York : McGraw-Hill, 2005, pp.42.

[3] W. D. Crano, and R. Prislin, Attitudes and Attitude Change, New York: Psychology Press. 2008, pp. 3.

[4] J.R. Martin, and R. David, Working with Discourse, Meaning beyond the Clause. New York: Continuum. 2007. pp. 28

[5] M.J.Z. Abidin, EFL Students' Attitudes towards Learning English Language: The Case of Libyan Secondary School Students, Penang: Canadian Center of Science and Education. Vol. 8. No. 2; February 2012. ISSN 1911-2017 E-ISSN 1911-2025 p.119-134.

[6] S. Eshghinejad, EFL Students' Attitudes toward Learning English Language: The case study of Kashan University students. Kashan: Journal of Cogen Education Eshghinejad, Cogent Education (2016), 3: 1236434. pp. 1-13.
[7] A. M, Huberman, M. B. Miles, and J. Saldana, Qualitative Data Analysis: A Methods Sourcebook (3rd ed). Arizona State University, CA: Sage. 2014. Pp.33.

[8] Y.S. Lincoln, and E.G. Guba, Naturalistic inquiry. Beverly Hills, California: Sage Publication. 1985. Pp.328

[9] J. Holmes, An Introduction to Sociolinguistics, $2^{\text {nd }}$ ed. Harlow: Pearson Education. 2001.

[10] D.R. Krathwohl, Methods of Educational and Social Science Research: An Integrated Approach White Plains, New York: Longman. 1993.

[11] S. Ahmed, S. Attitudes towards English Language Learning among EFL Learners at UMSKAL. Labuan: Journal of Education and Practice. ISSN 2222-1735 ISSN 2222-288X Vol.6, No.18, 2015. pp. 6-16.

[12] A. Asghar, I. Jamil, A. Iqbal, and M.Yasmin, Learner Attitude towards EFL Learning: A Response from Art and Design. Open Journal of Social Sciences, 2018, ISSN Online: 2327-5960. ISSN Print: 2327-5952. Scientific Research Publishing. 2018. pp. 81-88.

[13] V. Anuradha and M. Rengaraj, Students' Attitude towards English Language Learning and their Academic Achievement among First Year Engineering Graduates: A Case Study Indian Journal of Science and Technology, Vol 10(29), August 2017 ISSN (Print) : 0974-6846 ISSN (Online) : 0974-5645 pp 1-6.

[14] A. D. Abdulmohsen, Investigating English Major Students' Attitude Towards The Efficiency of the Conversation Course. Ardhya: International Journal of English Language Teaching, Vol.2,No.4, December 2014. pp.56-66.

[15] F. Munir and A.U Rehman, Attitudes of Secondary School Students towards English as Foreign Language: A case study at Lahore, Pakistan. International Journal of Research (IJR) e-ISSN: 2348-6848, p- ISSN: 2348-795X Volume 2, Issue 4, April 2015 pp. 637-650.

[16] E. Shvidko, Learners' Attitude toward English only Institutional Policies: Language Use Outside the Classroom. TSL Canada Journal, Vol. 34. Issue 2, 2017. pp.25-48.

[17] E. G. Burgos, and S. P.P. Chilean $12^{\text {th }}$ Graders' Attitude toward English as a Foreign Language. Chile: Theme Review. Colomb. Applied Linguistics Journal. Printed ISSN 0123-4641 Online ISSN 2248-7085 • July - December 2015. Vol. 17 - Number 2 pp. 313-324.

[18] I.S. Ahmad, Attitudes and Motivation toward Learning the English Language among Students from Islamic Education System Background: Exploring the Views of Teachers. Malaysia: Journal of Education and Learning, Vol. 8 (3) 2014. pp. 195-208

[19] H. A. Alsamadi and S.S. Ibnian, The Relationship between Saudi EFL Students' Attitudes towards Learning English and their Academic Achievement. International Journal of Education and Social Science www.ijessnet.com Vol. 2 No. 1; January 2015, pp. 92-102.

[20] E.H. Fadlalla, Students' Attitudes And Motivation Toward English Language. International Journal of English and Literature (IJEL). ISSN(P): 2249-6912; ISSN(E): 2249-8028. Vol. 7, Issue 2, Apr 2017, 55-64.

[21] T. A. A. B. Khaled, Attitudes towards Standard Arabic: A Case Study of Jordanian Undergraduate Students of English. International Journal of Linguistics. ISSN 1948-5425, 2014, Vol. 6, No. 4 pp. 154-171. 